\title{
Evaluating fish assemblages associated with gas platforms: Evidence from a visual census technique and experimental fishing surveys
}

\section{Evaluación de las comunidades de peces asociadas con plataformas gaseras: Evidencia de una técnica de censos visuales y estudios pesqueros experimentales}

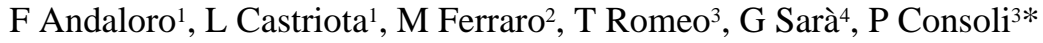 \\ ${ }^{1}$ ISPRA, c/o Residence Marbela, Via Salvatore Puglisi 9, 98143 Palermo, Italy. \\ 2 ENI Div. Exploration and Production, Servizio AMTE, Via Emilia 1, 20097 San Donato Milanese, Milano, Italy. \\ ${ }^{3}$ Dept. of Ecology, University of Palermo, Via delle Scienze, Ed. 16, I-90128 Palermo, Italy. \\ ${ }^{4}$ ISPRA, Laboratory of Milazzo, Via dei Mille 44, 98057 Milazzo, Messina, Italy. \\ * Corresponding author. E-mail: pierpaoloconsoli@hotmail.com
}

\begin{abstract}
Fish assemblages associated with extractive platforms were surveyed, for the first time, using traditional fishing surveys (bottom gill net) and an underwater visual census (UVC) technique in order to test the effectiveness and to identify strengths and weaknesses of both methods. The study was carried out during three seasons at two offshore gas platforms (Eleonora and Squalo C) located in the central Adriatic Sea. Both methods recorded a similar number of fish species although with only eight species in common, thus supplying complementary information and a good estimate of the total fish species richness (39) associated with these gas platforms. The use of innovative techniques, such as UVC, to explore the inner part of the platforms, allowed the censusing of several cryptobenthic species, mostly Blennidae (8 species), never recorded during previous studies. Even if both methods were able to detect temporal variability, only the UVC technique was able to highlight spatial changes between platforms, demonstrating their high efficiency regarding the quality of the scientific information supplied. The innovative method of studying biodiversity presented in this study appears to be highly reproducible and suitable for monitoring fish diversity in artificial and very complex habitats like gas platforms.
\end{abstract}

Key words: Adriatic Sea, fish assemblage, gas platforms, fishing survey, visual census.

RESUMEN. Se estudiaron, por primera vez, las comunidades de peces asociadas con plataformas extractivas mediante muestreos pesqueros tradicionales (red de enmalle de fondo) y una técnica de censos visuales submarinos para determinar la eficacia e identificar las fortalezas y debilidades de los dos métodos. El estudio se realizó durante tres estaciones del año en dos plataformas gaseras marinas (Eleonora y Squalo C) localizadas en el Mar Adriático central. Los dos métodos registraron una cantidad similar de especies ícticas, aunque solamente ocho especies en común, suministrando información complementaria y un buen cálculo de la riqueza total de las especies ícticas (39) asociadas con las plataformas gaseras. El uso de técnicas inovadoras, como los censos visuales submarinos, para explorar el interior de las plataformas permitió el censo de varias especies criptobentónicas, generalmente Blennidae (8 especies), que no se habían registrado en estudios anteriores. Aunque con los dos métodos se logró detectar la variabilidad temporal, sólo los censos visuales distinguieron los cambios espaciales entre las plataformas, demostrando así la calidad de la información científica suministrada. Este método inovador para estudiar la biodiversidad parece ser altamente reproducible y apropiado para observar la diversidad de peces en hábitats artificiales y complejos como lo son las plataformas gaseras.

Palabras clave: Mar Adriático, comunidad de peces, plataformas gaseras, muestreo pesquero, censos visuales.

\section{INTRODUCTION}

The extraction of fossil fuels from offshore fields has rapidly expanded in the last decades, becoming the leading activity in the exploitation of marine mineral resources. As a main consequence, thousands of offshore platforms have proliferated over the world's oceans and many more will likely be implemented in the future (Pulsipher and Daniel 2000). For this reason, understanding the role played by them in marine ecosystems becomes an important worldwide issue. The distribution and abundance of fish assemblages associated with gas and oil platforms have been studied in regions such as southern California, the Gulf of Mexico, western

\section{INTRODUCCIÓN}

La extracción de combustibles fósiles de campos mar adentro ha aumentado rápidamente en las últimas décadas, convirtiéndose en la principal actividad en la explotación de los recursos minerales marinos. Como principal consecuencia, han proliferado miles de plataformas costa afuera en los océanos del mundo y probablemente se instalarán muchos más en el futuro (Pulsipher y Daniel 2000). Por tal razón, la comprensión del papel que juegan en los ecosistemas marinos adquiere cada vez mayor importancia a nivel mundial. La distribución y abundancia de las comunidades de peces asociadas con plataformas gaseras y petroleras se han estudiado 
coast of Africa, and North Sea. In these areas, there was evidence that offshore platforms promote the aggregation of fishes that would otherwise be dispersed in larger areas of the ocean (Hastings et al. 1976; Olsen and Valdemarsen 1977; Valdemarsen 1979; Gallaway et al. 1981; Gerlotto et al. 1989; Stanley and Wilson 1990, 1991, 1997, 1998, 2000; Bull and Kendall 1994; Love et al. 1999; Jørgensen et al. 2002; Løkkeborg et al. 2002). As these structures extend throughout the entire water column, their effects are not limited to demersal fishes, but also involve pelagic species that are attracted either by the solid, reef-like nature of the structures, or by the smaller organisms foraging in the area (Gallaway and Lewbel 1982).

Until now, the assessment of fish diversity associated with extractive platforms has been mainly carried out by destructive methods, like fishing gears (Bombace et al. 1999; Fabi et al. 2002, 2004; Løkkeborg et al. 2002), and conservative methods, such as hydro-acoustic surveys (Stanley and Wilson 2000, Jørgensen et al. 2002, Soldal et al. 2002), video recordings from remotely operated vehicles (Cripps and Aabel 1995, Aabel et al. 1997), or submersible surveys (Love et al. 2000, 2005, 2006). In contrast, underwater visual census (UVC) techniques by scuba diving have been rarely employed (Carlisle et al. 1964, Rilov and Benayahu 2000, Consoli et al. 2007).

In this context, the main aim of this study was to combine an UVC technique and experimental fishing surveys in order to obtain complementary information and to test the effectiveness of these methods in describing fish assemblages associated with gas platforms. It is important to emphasize that the two methods are not directly comparable as they are totally different and they were performed at different times of the day and at different depths. For these reasons, advantages and disadvantages of both methods are discussed.

\section{MATERIAL AND METHODS}

\section{Study area}

The study was carried out at two offshore gas platforms, Eleonora and Squalo C, located in the central Adriatic Sea (Mediterranean Sea), about $17 \mathrm{~km}$ off the city of Pescara, Italy (fig. 1). The first is an eight-leg platform while the latter is a four-leg platform. Both platforms lie on a sand-muddy bottom in 59 and $80 \mathrm{~m}$ of water, respectively, and are fixed to the sea floor by concrete or steel legs, which are connected by an assemblage of cross beams.

\section{Sampling methods}

During summer 2005, autumn 2005, and spring 2006, fish assemblages were evaluated by experimental fishing surveys and the UVC technique.

Fish collections for the fishing surveys were made within a 50-m radius of the two platforms using an experimental en regiones como el sur de California, el Golfo de México, la costa occidental de África y el Mar del Norte. En estas áreas se encontró evidencia de que las plataformas mar adentro promueven la agrupación de peces que de otra manera se encontrarían dispersos en zonas más amplias del océano (Hastings et al. 1976; Olsen y Valdemarsen 1977; Valdemarsen 1979; Gallaway et al. 1981; Gerlotto et al. 1989; Stanley y Wilson 1990, 1991, 1997, 1998, 2000; Bull y Kendall 1994; Love et al. 1999; Jørgensen et al. 2002; Løkkeborg et al. 2002). Ya que estas estructuras se extienden a lo largo de la columna de agua, no sólo afectan a los peces demersales, sino también a las especies pelágicas que son atraidas ya sea por la naturaleza sólida, de tipo arrecifal, de las estructuras o por los organismos más pequeños que buscan alimento en el área (Gallaway y Lewbel 1982).

Hasta ahora, la evaluación de la diversidad íctica asociada con plataformas extractivas se ha realizado principalmente mediante métodos destructivos, como las artes de pesca (Bombace et al. 1999; Fabi et al. 2002, 2004; Løkkeborg et al. 2002), y métodos conservativos, como los muestreos hidroacústicos (Stanley y Wilson 2000, Jørgensen et al. 2002, Soldal et al. 2002), videos tomados desde vehículos operados por control remoto (Cripps y Aabel 1995, Aabel et al. 1997) o sumergibles (Love et al. 2000, 2005, 2006). En contraste, rara vez se han empleado las técnicas de censos visuales submarinos con equipo autónomo (Carlisle et al. 1964, Rilov y Benayahu 2000, Consoli et al. 2007).

En este contexto, el objetivo principal de este estudio fue combinar censos visuales submarinos y muestreos pesqueros experimentales a fin de obtener información complementaria y determinar la eficacia de tales métodos para describir las comunidades de peces asociadas con plataformas gaseras. Es importante enfatizar que ambos métodos no son directamente comparables ya que son totalmente distintos y se realizaron durante diferentes momentos del día y a diferentes profundidades; por lo tanto, se discuten las ventajas y desventajas de ambos métodos.

\section{MATERIALES Y MÉTODOS}

\section{Área de estudio}

El estudio se llevó a cabo en dos plataformas gaseras, Eleonora y Squalo C, localizadas en el Mar Adriático central (Mar Mediterráneo), alrededor de $17 \mathrm{~km}$ de la costa de Pescara, Italia (fig. 1). La primera es una plataforma de ocho postes y la segunda una plataforma de cuatro postes. Ambas plataformas yacen sobre un fondo arenoso y lodoso a profundidades de 59 y $80 \mathrm{~m}$, respectivamente, y están fijas al fondo del mar mediante postes de concreto o acero, los cuales se conectan por un armazón de barras cruzadas.

\section{Métodos de muestreo}

Durante el verano de 2005, el otoño de 2005 y la primavera de 2006, se evaluaron las comunidades de peces 


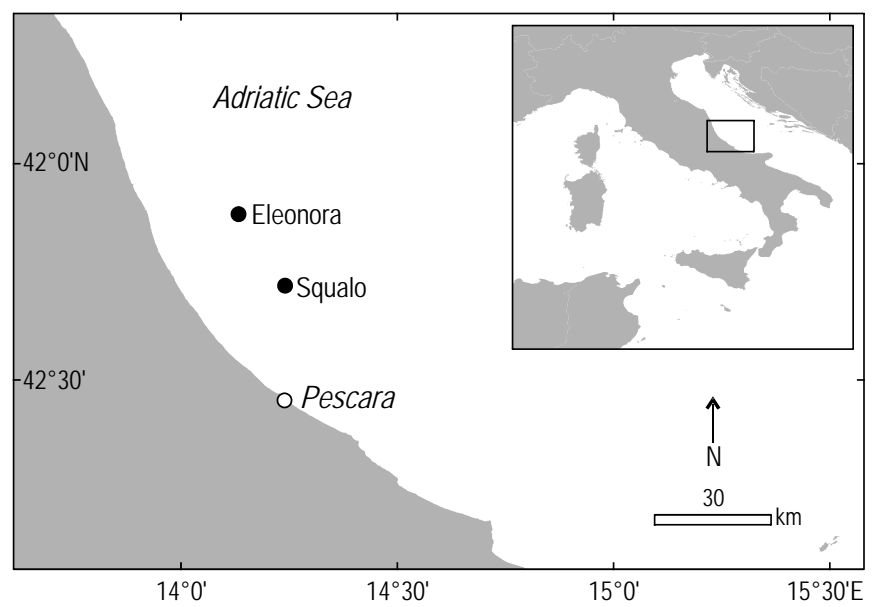

Figure 1. Study area showing the location of the gas platforms (black dots).

Figura 1. Área de estudio mostrando la localización de las plataformas gaseras (puntos negros).

monofilament bottom gill net (400 m long, $6 \mathrm{~m}$ high, $34 \mathrm{~mm}$ mesh size). The net was anchored close to the bottom and was lowered at dusk and hauled at dawn ( 12 h). Two replicates per season were performed at each platform, for a total of 12 hauls in the whole study period for both platforms.

The visual censuses were conducted by scuba divers. The dives were carried out randomly on horizontal units $(6 \mathrm{~m}$ high and with a $3 \mathrm{~m}$ radius from the pillar's surface) at depths of 0 to $18 \mathrm{~m}$. For each platform, 12 replicates per season were performed on pillars randomly extracted for a total of 72 censuses in the whole study period for both platforms.

Among the different possible visual census techniques, the mobile point count (MPC) method was chosen. This technique, specifically designed for offshore platforms (Rilov and Benayahu 2000), was successfully tested by Consoli et al. (2007), as it is particularly suited for studying species strictly associated with platform pillars and to detect benthic and cryptic species. For the MPC, scuba divers first recorded the more conspicuous and easily identifiable fish that were within $3 \mathrm{~m}$ of the pillars. Later, scuba divers swam very close to each pillar counting cryptobenthic species. Fish abundance was estimated by counting single specimens to a maximum of 10 individuals, and using abundance classes (11-30, 31-50, 51-100, 101-200, 201-500, >500 in the case of schools). This recording system reduced the error usually encountered by an analysis of a wide range of abundances, ensuring homogeneity of variance after log-transformation of the data (Frontier 1986, Guidetti et al. 2003).

\section{Data analyses}

To assess the adequacy of the number of samples for each technique, we used the statistical nonparametric method proposed by Chao et al. (2009). The method uses the Chao2 nonparametric estimator of asymptotic richness, which is mediante muestreos pesqueros experimentales y la técnica de censos visuales submarinos.

En los muestreos pesqueros experimentales, los peces se recolectaron dentro de un radio de $50 \mathrm{~m}$ de las dos plataformas con una red de enmalle de monofilamento ( $400 \mathrm{~m}$ de largo, $6 \mathrm{~m}$ de alto, $34 \mathrm{~mm}$ de luz de malla). La red, anclada cerca del fondo, se colocaba al anochecer y se recogía al amanecer ( $12 \mathrm{~h})$. Se realizaron dos réplicas por temporada en cada plataforma, para un total de 12 recolecciones durante todo el periodo de estudio para ambas plataformas.

Los censos visuales se realizaron mediante buceo con equipo autónomo alrededor de unidades horizontales $(6 \mathrm{~m}$ de altura y con un radio de $3 \mathrm{~m}$ de la superficie del pilar) a profundidades de 0 a $18 \mathrm{~m}$. En cada plataforma se realizaron 12 réplicas por temporada en pilares seleccionados de forma aleatoria para un total de 72 censos durante todo el periodo de estudio para ambas plataformas.

De entre las diferentes técnicas de censos visuales se escogió el método de conteo de puntos móviles. Este método, específicamente diseñado para plataformas mar adentro (Rilov y Benayahu 2000), fue éxitosamente probado por Consoli et al. (2007), ya que es particularmente favorable para estudiar especies estrictamente asociadas con pilares de plataformas y para detectar especies bentónicas y crípticas. Para los conteos, los buzos primero registraban los peces más conspícuos y fácilmente identificables dentro de $3 \mathrm{~m}$ de los pilares, y posteriormente nadaban muy cerca de cada pilar para contar las especies criptobentónicas. La abundancia de peces se estimó contando especímenes individuales hasta un máximo de 10 individuos, y usando clases de abundancia (11-30, 31-50, 51-100, 101-200, 201-500, >500 en el caso de cardúmenes). Este sistema redujo el error normalmente encontrado en un análisis de un amplio intervalo de abundancias, asegurando la homogeneidad de varianza después de la transformación logarítmica de los datos (Frontier 1986, Guidetti et al. 2003).

\section{Análisis de datos}

Para evaluar la suficiencia de las muestras para cada técnica, se utilizó el método estadístico no paramétrico propuesto por Chao et al. (2009). Tal método usa el estimador no paramétrico de riqueza asintótica Chao2, el cual se basa en las frecuencias de especies poco comunes en los datos originales de muestreo:

$$
S_{\text {est }}=S_{o b s}+(1-1 / t) Q_{1}^{2} /\left(2 Q_{2}\right)
$$

donde $S_{\text {est }}$ es la riqueza de especies asintótica estimada, $S_{\text {obs }}$ es la riqueza de especies observada, $t$ es el número de muestras recolectadas, $Q_{1}$ es el número de especies representadas por exactamente una muestra (“únicas”) y $Q_{2}$ es el número de especies representadas por exactamente dos muestras (“duplicadas”). El número adicional de muestras necesarias 
based on the frequencies of rare species in the original sampling data:

$$
S_{\text {est }}=S_{o b s}+(1-1 / t) Q_{1}^{2} /\left(2 Q_{2}\right)
$$

where $S_{\text {est }}$ is the estimated asymptotic species richness, $S_{o b s}$ is the observed species richness, $t$ is the number of samples collected, $Q_{1}$ is the number of species represented by exactly one sample ("uniques"), and $Q_{2}$ is the number of species represented by exactly two samples (“duplicates"). The additional number of samples needed to reach the asymptotic Chao2 estimate is equal to $m=t x^{*}$, where $x^{*}$ is the solution of the following equation:

$$
2 Q_{1}(1+x)=\exp \left[x \frac{2 Q_{2}}{(1-1 / t) Q_{1}+2\left(Q_{2} / t\right)}\right]
$$

To reach a fraction $g$ (including 100\%, 95\%, and 90\%) of $S_{\text {est }}$ for sample-based data, the required number of additional samples is:

$$
m_{g} \approx \frac{\log \left[1-\frac{t}{(t-1)} \frac{2 Q_{2}}{Q_{1}^{2}}\left(g S_{e s t}-S_{o b s}\right)\right]}{\log \left[1-\frac{2 Q_{2}}{(t-1) Q_{1}+2 Q_{2}}\right]}
$$

In order to verify the existence of differences in the fish assemblage in relation to temporal and spatial variability, a two-way crossed permutational multivariate analysis of variance (PERMANOVA, Anderson 2001) was performed for each data set (fishing and UVC). For both data sets, a multivariate analysis of variance was used to test for differences between seasons (three levels, fixed) and platforms (two levels, fixed). The analysis was based on Gower distances and under 4999 permutations. A permutation analysis of multivariate dispersions (PERMDISP, Anderson 2004) was also computed to detect differences in dispersion inside each group. Prior to the analyses, data were transformed to $\log (x+1)$ to reduce the weighting of the abundant categories and increase that of the rarer ones. Since both methods were implemented at different depths, data were analyzed separately.

\section{RESULTS}

Overall, a total of 45 fish species was recorded by the fishing and UVC techniques at both gas platforms (Eleonora and Squalo C). A comparable total number of species (total species richness) was recorded by the fishing surveys (28 taxa belonging to 19 families) and UVC method (29 taxa belonging to 12 families); however, only eight species were common to both techniques (table 1). As for UVC, the para alcanzar el estimador asintótico Chao2 es igual a $m=$ $t x^{*}$, donde $x^{*}$ es la solución de la siguiente ecuación:

$$
2 Q_{1}(1+x)=\exp \left[x \frac{2 Q_{2}}{(1-1 / t) Q_{1}+2\left(Q_{2} / t\right)}\right]
$$

Para alcanzar una fracción $g$ (incluyendo 100\%, 95\% y $90 \%)$ de $S_{\text {est }}$ para los datos basados en la muestra, el número necesario de muestras adicionales es:

$$
m_{g} \approx \frac{\log \left[1-\frac{t}{(t-1)} \frac{2 Q_{2}}{Q_{1}^{2}}\left(g S_{e s t}-S_{o b s}\right)\right]}{\log \left[1-\frac{2 Q_{2}}{(t-1) Q_{1}+2 Q_{2}}\right]}
$$

Para verificar la existencia de diferencias en la comunidad de peces en cuanto a la variabilidad temporal y espacial, se realizó un análisis de varianza multivariado de dos vías con base en permutaciones (PERMANOVA, Anderson 2001) para cada grupo de datos (muestreos pesqueros y censos visuales). Para ambos grupos de datos, se empleó un análisis de varianza multivariado para detectar diferencias entre estaciones del año (tres niveles, fijos) y plataformas (dos niveles, fijos). El análisis se basó en distancias de Gower, bajo 4999 permutaciones. También se realizó un análisis permutacional de la dispersión multivariada (PERMDISP, Anderson 2004) para detectar diferencias en dispersión dentro de cada grupo. Previo a los análisis, los datos fueron transformados a $\log (x+1)$ para reducir el peso de las categorías abundantes e incrementar el de las menos comunes. En vista de que los dos métodos se implementaron a diferentes profundidades, los datos se analizaron por separado.

\section{RESULTADOS}

En total, se registraron 45 especies de peces mediante los muestreos pesqueros y los censos visuales submarinos en ambas plataformas gaseras (Eleonora y Squalo C). Se registró un número total de especies comparable (riqueza total de especies) para los muestreos pesqueros (28 taxones pertenecientes a 19 familias) y los censos visuales (29 taxones pertenecientes a 12 familias), aunque sólo se encontraron ocho especies en común (tabla 1). En los conteos visuales, las familias Blennidae y Sparidae fueron las más representativas, con ocho especies cada una.

En cuanto a la suficiencia de las muestras para cada método (tabla 2), 12 muestreos pesqueros recolectaron 92\% (28 especies) del número total de especies estimado (30 especies), lo cual significa que se necesitarían dos muestras adicionales para alcanzar $95 \%(g=0.95)$ de $S_{\text {est }}$. Por otro lado, 72 censos visuales detectaron sólo $88 \%$ del número total de especies estimado, por lo que se necesitarían 13 muestras adicionales para detectar $95 \%(g=0.95)$ de $S_{\text {est }}$. 
families Blennidae and Sparidae were the most representative with eight species each.

Regarding the adequacy of the number of samples for each technique (table 2), 12 fishing surveys were able to collect $92 \%$ (28 species) of the estimated total number of species (30 species). This means that two additional samples would be needed to reach 95\% $(g=0.95)$ of $S_{\text {est }}$. On the contrary, 72 visual censuses were capable of detecting only $88 \%$ of the estimated total number of species, such that 13 additional samples would be necessary to detect $95 \%$ $(g=0.95)$ of $S_{\text {est }}$.

For both methods, PERMANOVA demonstrated that fish communities differed among sampling seasons. The fish
Para ambos métodos, el PERMANOVA demostró que las comunidades de peces difirieron entre las temporadas de muestreo. La comunidad de peces detectada mediante conteos visuales fue diferente en función del factor "plataforma" (tabla 3). El PERMDISP no mostró dispersión significativa para ambos métodos según los factores "plataforma" y “temporada” (tabla 4).

\section{DISCUSIÓN}

Este estudio permitió identificar las fortalezas y las debilidades tanto de los muestreos pesqueros como de los censos visuales submarinos como herramientas para estudiar

Table 1. Fish taxa recorded by fishing and underwater visual census (UVC) techniques at both platforms. Habitat: $B=$ benthic, $\mathrm{NB}=$ necto-benthic, and $\mathrm{P}=$ pelagic.

Tabla 1. Taxones de peces registrados mediante muestreos pesqueros y censos visuales submarinos (UVC) en ambas plataformas. Hábitat: $\mathrm{B}$ = bentónico, NB = nectobentónico y $\mathrm{P}$ = pelágico.

\begin{tabular}{|c|c|c|c|c|c|}
\hline \multicolumn{3}{|c|}{ Fishing } & \multicolumn{3}{|c|}{ UVC } \\
\hline Arnoglossus laterna & $\mathrm{B}$ & Yes & Aidablennius sphynx & $\mathrm{B}$ & Yes \\
\hline Boops boops & $\mathrm{P}$ & & Balistes carolinensis & NB & Yes \\
\hline Chelidonichtys lucerna & $\mathrm{B}$ & Yes & Boops boops & $\mathrm{P}$ & \\
\hline Conger conger & B & Yes & Chromis chromis & NB & Yes \\
\hline Engraulis encrasicolus & $\mathrm{P}$ & Yes & Dentex dentex & NB & Yes \\
\hline Lophius piscatorius & $\mathrm{B}$ & Yes & Dicentrarcus labrax & NB & Yes \\
\hline Merlangius merlangius & NB & Yes & Diplodus puntazzo & NB & Yes \\
\hline Merluccius merluccius & NB & Yes & Diplodus sargus & NB & Yes \\
\hline Mullus barbatus & B & Yes & Diplodus vulgaris & NB & \\
\hline Raja asterias & $\mathrm{B}$ & Yes & Oblada melanura & NB & Yes \\
\hline Sardina pilchardus & $\mathrm{P}$ & & Parablennius gattoruggine & $\mathrm{B}$ & Yes \\
\hline Scomber japonicus & $\mathrm{P}$ & Yes & Parablennius incognitus & B & Yes \\
\hline Scorpaena notata & B & & Parablennius rouxi & B & Yes \\
\hline Scorpaena porcus & $\mathrm{B}$ & & Parablennius zvonimiri & B & Yes \\
\hline Scorpaena scrofa & $\mathrm{B}$ & Yes & Sarda sarda & $\mathrm{P}$ & Yes \\
\hline Serranus cabrilla & NB & & Sardina pilchardus & $\mathrm{P}$ & \\
\hline Serranus hepatus & NB & Yes & Scorpaena notata & B & \\
\hline \multirow[t]{2}{*}{ Uranoscopus scaber } & $\mathrm{B}$ & Yes & Spondiliosoma chantarus & NB & Yes \\
\hline & & & Trachurus sp. & $\mathrm{P}$ & \\
\hline
\end{tabular}


assemblage as detected by UVC was different as a function of the factor "platform" (table 3). PERMDISP did not show significant dispersion for both methods according to the factors "platform" and "season" (table 4).

\section{Discussion}

The present study allowed the identification of the strengths and weaknesses of UVC and fishing techniques as tools for studying the fish diversity and fish assemblages associated with offshore gas platforms.

The statistical nonparametric method proposed by Chao et al. (2009) indicated that fishing surveys were able to collect $92 \%$ of the estimated fish diversity, while visual censuses were capable of detecting only $88 \%$, even though la diversidad íctica y las comunidades de peces asociadas con plataformas gaseras mar adentro.

El método estadístico no paramétrico propuesto por Chao et al. (2009) mostró que los muestreos pesqueros detectaron 92\% de la diversidad íctica estimada, mientras que los censos visuales sólo pudieron detectar $88 \%$, a pesar de que el número de muestreos pesqueros y censos visuales realizados fue diferente (12 y 72, respectivamente).

Tal resultado se puede atribuir a la selectividad del arte de pesca; de hecho, es bien conocido que las redes de enmalle y trasmallo son lo suficientemente selectivas y que 12 muestreos pesqueros son suficientes para detectar la mayoría de la diversidad íctica. Por otro lado, se requieren 72 censos visuales para obtener una estimación razonable de la riqueza de especies. No obtstante, ambos métodos registraron un

Table 2. Estimated sampling effort for fishing and underwater visual census (UVC) data. Abbreviations are: $t$, collected samples; $T$, total number of incidences; $S_{o b s}$, observed species richness; $S_{\text {est }}$, estimated asymptotic species richness; $Q_{1}$, number of species represented by exactly one sample (“uniques”); $Q_{2}$, number of species represented by exactly two samples (“duplicates”); $q_{0}$, probability that the next observed sample contains a species new to the survey (i.e., the proportion of species in the next sample that are new to the survey), estimated as $\mathrm{Q}_{1} / T$; and $g$, target fraction of $S_{\text {est }}$ that is to be reached. The entries in each $g$ column represent the number of additional samples needed to reach 100\% $(g=1)$ and 95\% $(g=0.95)$, respectively, of $S_{\text {est }}$.

Tabla 2. Esfuerzo de muestreo estimado para los datos de los muestreos pesqueros y los censos visuales submarinos (UVC). Abreviaciones: $t$, muestras recolectadas; $T$, número total de ocurrencias; $S_{o b s}$, riqueza de especies observada; $S_{\text {est }}$, riqueza de especies asintótica estimada; $Q_{1}$, número de especies representadas por exactamente una muestra (“únicas”); $Q_{2}$, número de especies representadas por exactamente dos muestras (“duplicadas”); $q_{0}$, probabilidad de que la próxima muestra observada contenga una especie nueva al muestreo (i.e., la proporción de especies en la próxima muestra que son nuevas para el estudio), estimada como $\mathrm{Q}_{1} / T$; y $g$, fracción objetiva de $S_{\text {est }}$ que deberá alcanzarse. Los registros en cada columna de $g$ representan el número de muestras adicionales necesarias para alcanzar 100\% $(g=1)$ y $95 \%(g=0.95)$, respectivamente, de $S_{e s t}$.

\begin{tabular}{lcccccccccc}
\hline Method & $t$ & $T$ & $S_{o b s}$ & $S_{\text {est }}$ & $Q_{1}$ & $Q_{2}$ & $q_{0}$ & $g=1$ & $g=0.95$ & $g=0.90$ \\
\hline Fishing & 12 & 117 & 28 & 30 & 6 & 7 & 0.05 & 20 & 2 \\
UVC & 72 & 847 & 29 & 33 & 5 & 3 & 0.07 & 223 & 54 & 13 \\
\hline
\end{tabular}

¥ For this case, $g$ must be greater than 0.926 because of the restriction $g S_{\text {est }}>S_{\text {obs }}$.

Table 3. Nonparametric multivariate analysis of variance (PERMANOVA) on the basis of Bray-Curtis dissimilarities for fish assemblages after square root transformation.

Tabla 3. Análisis de varianza multivariado no paramétrico (PERMANOVA) con base en las disimilitudes de Bray-Curtis para las comunidades de peces después de la transformación de la raíz cuadrada.

\begin{tabular}{lccccc}
\hline Source & d.f. & SS & MS & $F$ & $P$ \\
\hline Fishing & 2 & 7613 & 3807 & 2.741 & 0.007 \\
Season & 1 & 3522 & 3522 & 2.536 & 0.065 \\
Platform & 2 & 1464 & 732.1 & 0.527 & 0.863 \\
Season $\times$ platform & 6 & 8333 & 1389 & & \\
Residuals & 11 & 20932 & & & \\
Total & & & & & \\
\hline UVC & 2 & 6412 & 3206 & 67.055 & 0.002 \\
Season & 1 & 2540 & 2540 & 5.312 & 0.004 \\
Platform & 2 & 1961 & 980.4 & 20.507 & 0.098 \\
Season $\times$ platform & 66 & 31554 & 478.1 & & \\
Residuals & 71 & 42466 & & & \\
Total & & & & & \\
\hline
\end{tabular}


Table 4. Results of the permutational analysis of multivariate dispersions.

Tabla 4. Resultados del análisis permutacional de dispersiones multivariadas.

\begin{tabular}{lccrcc}
\hline & \multicolumn{2}{c}{ Fishing } & & \multicolumn{2}{c}{ UVC } \\
\cline { 2 - 3 } \cline { 5 - 6 } Factor & $F$ & $P$ & & $F$ & $P$ \\
\hline Season & 4.181 & 0.104 & & 1.269 & 0.391 \\
Platform & 0.603 & 0.615 & & 0.295 & 0.658 \\
\hline
\end{tabular}

the number of surveys performed with fishing and UVC techniques was different (12 and 72, respectively).

Such a result could be due to the selectivity of the fishing gear; in fact, it is well known that gill and trammel nets are sufficiently selective and that 12 fishing surveys are enough to detect most of the fish diversity. On the other hand, 72 surveys using the UVC technique are needed to provide a reasonable estimate of the species richness. However, both techniques recorded a similar number of fish species with only eight species in common, thus supplying complementary information and a good estimate of the total fish species richness (39) associated with these gas platforms. In particular, the use of innovative techniques such as UVC, to explore the inner part of the platforms, allowed the census of several species exclusive to this technique and never recorded during previous studies carried out in the same area (Bombace et al. 1999; Fabi et al. 2002, 2004). Most of those species (27\% of the total number of species recorded by UVC) belong to the category of cryptobenthic species, mostly Blennidae (eight species). They live very close to hard surfaces of platforms, likely both for trophic and reproductive reasons. Such behaviour of Blennidae is in agreement with other observations showing that these fish usually hide inside the internal structures of oil rigs and evade capture both due to their small size and the difficulty in positioning passive fishing gear (Bombace et al. 1999; Fabi et al. 2002, 2004) close to the rigs (Soldal et al. 2002).

Though both techniques were able to detect temporal variability, only the visual censuses were able to highlight spatial changes between platforms. The UVC technique, however, does have special challenges. Water depth and temperature, water transparency, currents, and limited bottom time will all affect diving operations (table 5). In particular, the time at the observer's disposal is generally limited and collected data cannot be revised. Some observer-related factors can affect the in situ location and identification of species. In addition, the diver's presence can considerably influence the behaviour of some species. Nevertheless, there are also a number of advantages to visual censuses compared with fish sampling using nets. As outlined above, benthic fishes sheltering within reefs are efficaciously detected only through in situ observation. Moreover, the UVC technique employed (MPC) is suitable for collecting both qualitative (species diversity, composition, and spatial distribution) and número similar de especies de peces, de los cuales sólo ocho fueron comunes, proporcionando así información complementaria y un buen cálculo de la riqueza total de especies ícticas (39) asociadas con plataformas gaseras. En particular, el uso de técnicas inovadoras como los conteos visuales para explorar la parte interior de las plataformas, permitió censar varias especies que no habían sido registradas en estudios anteriores realizados en la misma zona (Bombace et al. 1999; Fabi et al. 2002, 2004). La mayoría de esas especies (27\% del número total de especies registradas mediante censos visuales) pertenecen a la categoría de especies criptobentónicas, principalmente de la familia Blennidae (ocho especies), las cuales viven muy cerca de estructuras duras de las plataformas probablemente por razones tanto tróficas como reproductivas. Tal comportamiento de estas especies concuerda con otras observaciones que indican que estos peces normalmente se esconden entre las estructuras internas de las plataformas y evaden la captura debido a su tamaño pequeño y a la dificultad de posicionar las artes de pesca pasiva (Bombace et al. 1999; Fabi et al. 2002, 2004) cerca de los pilares (Soldal et al. 2002).

Aunque ambos métodos lograron detectar la variabilidad temporal, sólo los conteos visuales pudieron distinguir los cambios espaciales entre plataformas; sin embargo, las técnicas de censos visuales submarinos presentan ciertas desventajas. La profundidad, temperatura y transparencia del agua, así como las corrientes y el tiempo limitado en el fondo pueden afectar las operaciones de buceo (tabla 5). En particular, el observador generalmente dispone de tiempo limitado y los datos recolectados no se pueden revisar. Algunos factores relacionados con los observadores pueden afectar la localización e identificación de especies in situ. Además, la presencia del buzo puede afectar considerablemente el comportamiento de algunas especies. No obstante, los censos visuales también presentan varias ventajas en comparación con los muestreos pesqueros usando redes. Como ya se mencionó, la detección eficaz de peces bentónicos que se refugian dentro de arrecifes sólo es posible mediante observaciones in situ. Además, el método de censos visuales empleado (conteo de puntos móviles) es adecuado para recolectar datos tanto cualitativos (diversidad, composición y distribución espacial de especies) como cuantitativos (densidad y estructura de tallas); de hecho, el tamaño del área muestreada se conoce y establece antes del censo. La razón del número de individuos censados por área muestreada permite cuantificar la densidad de especies. El uso de artes de pesca estáticos, tal como redes fijas, también permite obtener datos cualitativos y cuantitativos, pero no permite calcular la superficie (o volumen) del área muestreada. Por tanto, debido a los datos complementarios que proporcionan, podría ser ventajoso emplear de forma conjunta técnicas de censos visuales y de muestreo directo, especialmente cuando se pretende caracterizar toda la comunidad de peces (Relini et al. 1995).

El método inovador para estudiar la biodiversidad que se presenta en este estudio parece ser altamente reproducible y 
quantitative data (density and size structure); in fact, the size of the surveyed area is known and established before censusing. The number of censused individuals per surveyed area ratio allows us to quantify species density. Using static fishing gears such as set nets, it is also possible to obtain qualitative and quantitative data, but they do not allow the surface (or volume) of the sampled area to be calculated. Due to their complementarities in terms of collected data, it could nevertheless be advantageous to couple visual census and direct sampling methods, especially when one is interested in characterizing the entire fish assemblage (Relini et al. 1995).

The innovative method of studying biodiversity presented in this study appears to be highly reproducible and suitable for monitoring fish diversity in such complex and artificial habitats like gas platforms. As assessing biodiversity in these highly complex contexts is a challenge for the near future, a reliable method would be able to influence the international research in this field. Indeed, these techniques are highly specific, cost-effective, and sufficiently affordable for all research teams to get both accurate and highly repeatable data. In conclusion, the above-mentioned considerations could allow for the lowering of the costs of future surveys aimed at studying fish assemblages associated with extractive platforms.

\section{ACKNOWLEDGEMENTS}

The authors are grateful to $\mathrm{W}$ Mentesana for directing underwater operations, and to FM Passarelli, G Scotti, E Azzurro, E Mostarda, U Scacco, M Dalù, V Esposito, and P Battaglia for technical assistance.

\section{REFERENCES}

Aabel JP, Cripps S, Kjeilen G. 1977. Oil and gas production structures as artificial reefs. In: Jensen AC (eds.), European Artificial Reef Research. Proc. 1st EARRN Conference, Ancona, Italy, 26-30 March 1996. Southampton Oceanography Centre, pp. 391-404.

Anderson MJ. 2001. A new method for non-parametric multivariate analysis of variance. Austral Ecol. 26: 32-46.

Anderson MJ. 2004. PERMDISP: A FORTRAN computer program for permutatinoal analysis of multivariate dispersions (for any two-factor ANOVA design) using permutation tests. Department of Statistics, University of Auckland, New Zealand.

Bombace G, Fabi F, Rivas G. 1999. Effetti sul popolamento ittico indotti da una piattaforma estrattiva dell'alto Adriatico: Prospettive di gestione delle risorse costiere. Biol. Mar. Medit. 6: 64-72.

Bull AS, Kendall JJ Jr. 1994. An indication of the process: Offshore platforms as artificial reefs in the Gulf of Mexico. Bull. Mar. Sci. 55: 1086-1098.

Carlisle JG, Turner CH, Ebert EE. 1964. Artificial habitat in the marine environment. Calif. Dept. Fish Game, Fish. Bull. 124: $93 \mathrm{pp}$.

Chao A, Colwell RK, Lin C, Gotelli NJ. 2009. Sufficient sampling for asymptotic minimum species richness estimators. Ecology 90: 1125-1133.
Table 5. Advantages and disadvantages of underwater visual census (UVC) and fishing (set net) techniques.

Tabla 5. Ventajas y desventajas de los censos visuales submarinos (UVC) y los muestreos pesqueros (con red fija).

\begin{tabular}{lll}
\hline Descriptors & UVC & Fishing \\
\hline Characteristics & Medium & Medium \\
Costs & High & Medium \\
Efficiency & High & High \\
Identification & Inner and external & External \\
Sectors & Low & Low \\
Spatial cover & None & Yes \\
Impact on community & High & Medium \\
Adequate for diversity & Low & High \\
Adequate for biomass & Medium & None \\
Behaviour interactions & Low & High \\
Selectivity & & \\
& & \\
Ecological groups & High & None \\
Cryptobenthic species & High & High \\
Nectobenthic species & High & High \\
Nectonic species & & \\
Abiotic factors & Not with low temp. & All \\
Temperature & High & All \\
Visibility & None or low & All \\
Current & Duperficial & All \\
Depth & & All \\
Light & & \\
\hline
\end{tabular}

adecuado para monitorear la diversidad íctica en hábitats complejos y artificiales como lo son las plataformas gaseras. La evaluación de la biodiversidad en estos lugares tan complejos representa un reto en el futuro cercano, y un método confiable podría influenciar la investigación internacional en este campo. Estas técnicas son muy específicas, de rentabilidad efectiva y lo suficientemente económicas para que los grupos de investigación puedan obtener datos precisos así como repetibles. En conclusión, tales consideraciones podrían bajar los costos de futuros muestreos cuyo objetivo es estudiar las comunidades de peces asociadas con plataformas extractivas.

\section{Agradecimientos}

Los autores agradecen W Mentesana quien dirigió las operaciones submarinas, así como FM Passarelli, G Scotti, E Azzurro, E Mostarda, U Scacco, M Dalù, V Esposito y P Battaglia su asistencia técnica.

Traducido al español por Christine Harris. 
Consoli P, Azzurro E, Sarà G, Ferraro M, Andaloro F. 2007. Fish diversity associated with gas platforms: Evaluation of two underwater visual census techniques. Cienc. Mar. 33:121-132.

Cripps SJ, Aabel JP. 1995. DP1-Fish survey using ROV data. RFRogaland Res. Rep. No. Rf-95/301. Stavanger, Norway, 12 pp.

Fabi G, Grati F, Lucchetti A, Trovarelli L. 2002. Evolution of the fish assemblage around a gas platform in the northern Adriatic Sea. ICES J. Mar. Sci. 59: 309-315.

Fabi G, Grati F, Puletti M, Scarcella G. 2004. Effects on fish community induced by the installation of two gas platforms in the Adriatic Sea. Mar. Ecol. Prog. Ser. 273: 187-197.

Frontier S. 1986. La méthode des cotations d'abondance appliquée aux pêcheries artisanales. In: Frontier S (ed.), Evaluation et optimisation des plans d'échantillonnage en écologie littorale. Ed. Piren, ATP 9-82-65. Centre National de la Recherche Scientifique, Paris, pp. 262-285.

Gallaway BJ, Lewbel GS. 1982. The ecology of petroleum platforms in the northwestern Gulf of Mexico: A community profile. FWS/OBS-82/27, US Fish and Wildlife Service, 92 pp.

Gallaway BJ, Martin LR, Howard RL, Boland GS, Dennis GD. 1981. Effects on artificial reef and demersal fish and macrocrustacean communities. Mar. Sci. 14: 237-299.

Gerlotto F, Bercy C, Bordeau B. 1989. Echo integration survey around offshore oil extraction platforms off Cameroon: Observations of the repulsive effect on fish of some artificially emitted sounds. Proc. Institute of Acoustics 19: 79-88.

Guidetti P, Fraschetti S, Terlizzi A, Boero F. 2003. Distribution patterns of sea urchins and barrens in shallow Mediterranean rocky reefs impacted by the illegal fishery of the rock-boring mollusc Lithophaga lithophaga. Mar. Biol. 143: 1135-1142.

Hastings RW, Ogren LH, Mabry MT. 1976. Observations on fish fauna associated with offshore platforms in the northeastern Gulf of Mexico. Fish. Bull. 74: 387-340.

Jørgensen T, Løkkeborg S, Soldal AV. 2002. Residence of fish in the vicinity of a decommissioned oil platform in the North Sea. ICES J. Mar. Sci. 59: 288-293.

Løkkeborg S, Humborstad OB, Jørgensen T, Soldal AV. 2002. Spatio-temporal variations in gillnet catch rates in the vicinity of North Sea oil platforms. ICES J. Mar. Sci. 59: 294-299.

Love MS, Caselle JE, Snook L. 1999. Fish assemblages on mussel mounds surrounding seven oil platforms in the Santa Barbara Channel and Santa Marina Basin. Bull. Mar. Sci. 65: 497-513.

Love MS, Caselle JE, Snook L. 2000. Fish assemblages around seven oil platforms in the Santa Barbara Channel area. Fish. Bull. 98: 96-117.
Love MS, Schroeder DM, Lenarz WH. 2005. Distribution of bocaccio (Sebastes paucispinis) and cowcod (Sebastes levis) around oil platforms and natural outcrops off California with implications for larval production. Bull. Mar. Sci. 77: 397-408.

Love MS, Schroeder DM, Lenarz WH, MacCall A, Scarborough Bull A, Thorsteinson L. 2006. Potential use of offshore marine structures in rebuilding an overfished rockfish species, bocaccio (Sebastes paucispinis). Fish. Bull. 104: 383-390.

Olsen S, Valdemarsen JW. 1977. Fish distribution studies around offshore installations. ICES CM 1977/B: 41.

Pulsipher AG, Daniel WB. 2000. Onshore disposition of offshore oil and gas platforms: Western politics and international standards. Ocean Coast. Manage. 43: 973-995.

Relini M, Torchia G, Relini G. 1995. Fish population pattern in a coastal artificial habitat in the NW Mediterranean. In: Eleftheriou A, Ansell A, Smith GJ (eds.), Proc. 28th European Marine Biology Symposium, Crete. Olsen and Olsen, Fredensborg, Denmark, pp. 359-368.

Rilov G, Benayahu Y. 2000. Fish assemblage on natural versus vertical artificial reefs: The rehabilitation perspective. Mar. Biol. 136: 931-942.

Soldal AV, Svellingen I, Jorgensen T, Lokkeborg S. 2002. Rigs-toreefs in the North Sea: Hydroacoustic quantification of fish in the vicinity of a "semi-cold" platform. ICES J. Mar. Sci. 59: 281-287.

Stanley DR, Wilson CA. 1990. A fishery-dependent based study of fish species composition and associated catch rates around oil and gas structures off Louisiana. Fish Bull. 88: 719-730.

Stanley DR, Wilson CA. 1991. Factors affecting the abundance of selected fishes near oil and gas platforms in the northern Gulf of Mexico. Fish Bull. 89: 149-159.

Stanley DR, Wilson CA. 1997. Seasonal and spatial variation in the abundance and size distribution of fishes associated with a petroleum platform in the northen Gulf of Mexico. Can. J. Fish. Aquat. Sci. 54: 1166-1176.

Stanley DR, Wilson CA. 1998. Spatial variation in fish density at three petroleum platforms as measured with dual-beam hydroacoustics. Gulf Mex. Sci. 16: 73-82.

Stanley DR, Wilson CA. 2000. Variation in the density and species composition of fishes associated with three petroleum platforms using dual beam hydroacoustics. Fish. Res. 47: 161-172.

Valdemarsen JW. 1979. Behaviour aspects of fish in relation to oil platforms in the North Sea. ICES CM 1979/B 27: 11 pp.

Received February 2010;

accepted September 2010. 